\title{
Fire History at the Forest-Grassland Eco- tone in Southwestern Montana
}

\author{
STEPHEN F. ARNO AND GEORGE E. GRUELL
}

\begin{abstract}
The history and influence of fires was studied at the forestgrassland ecotone in high valleys of southwestern Montana. Investigations were focused upon several sites having early landscape photographs and modern retakes that allow for detection of vegetational changes. Fire intervals were determined for these sites by analyzing fire scars on trees. Prior to 1910 , mean fire intervals at Pseudotsuga forest-grassland ecotones were 35 to 40 years, and probably shorter in grassland proper. No fires were detected on the study a reas after 1918. Photographic comparisons and field inspections show a substantial increase in mountain big sagebrush (Artemisia tridentata subsp. vaseyana) and conifers since 1900 .
\end{abstract}

In 1979 a study of vegetative changes in the Northern Rocky Mountains was initiated based upon retakes of historical landscape photographs, similar to the work of Gruell (1980) in Wyoming. The photographic comparisons included several from the high-elevation ( 1680 to $2130 \mathrm{~m}, 5,500$ to $7,000 \mathrm{ft}$ ) sagebrush-grass valleys of southwestern Montana (principally mountain big sagebrush, Artemisia tridentata subsp. vaseyana). Comparisons between the late 1800's or early 1900's scenes and the present vegetation showed the following trend: Sagebrush coverage has increased, conifer forests have thickened, and trees have spread down slope into former grass or sagebrush communities (Figs. 1 and 2). Sindelar (1971) and Patten (1969) reported similar successional patterns and descriptions by early journalists-e.g., Lewis and Clark (Thwaites 1959), Granville Stuart (Phillips 1925), and Hayden (1872)-suggest that grass-dominated communities were formerly more extensive.

The same journals and others refer to wildfires, and, considering that big sagebrush and young conifers are fire-sensitive, we wondered to what extent fire had influenced these vegetative changes. Numerous studies have recognized the importance of wildfires in Rocky Mountain forests and grasslands (Alexander 1979, Arno 1980, Stokes and Dieterich 1980, Wright et al. 1979). However, there are few data on presettlement fire frequencies in the highelevation sagebrush-grass valleys, except in northern Yellowstone Park (Houston 1973).

High-elevation sagebrush-grass communities cover several million acres in southwestern Montana (Morris et al. 1976) and adjacent portions of Idaho, and successional changes in these communities are important in management of both range and wildlife habitat. There is a need to improve knowledge of the successional status of big sagebrush and its relationship to past wildfires. This knowledge could be used by land managers in evaluating the application of prescribed fire for enhancing productivity of range and wildlife habitat. Thus, we decided to investigate fire history at photo-comparison sites in southwestern Montana. We focused the investigation on the forest/sagebrush-grassland ecotones because here old growth trees and stumps could provide fire-scar records dating back several centuries.

\footnotetext{
Authors are forest ecologist and research wildlife biologist, Intermountain Forest and Range Experiment Station, Northern Forest Fire Laboratory, Missoula, Mont. 59806.

Manuscript received March 24, 1982.
}

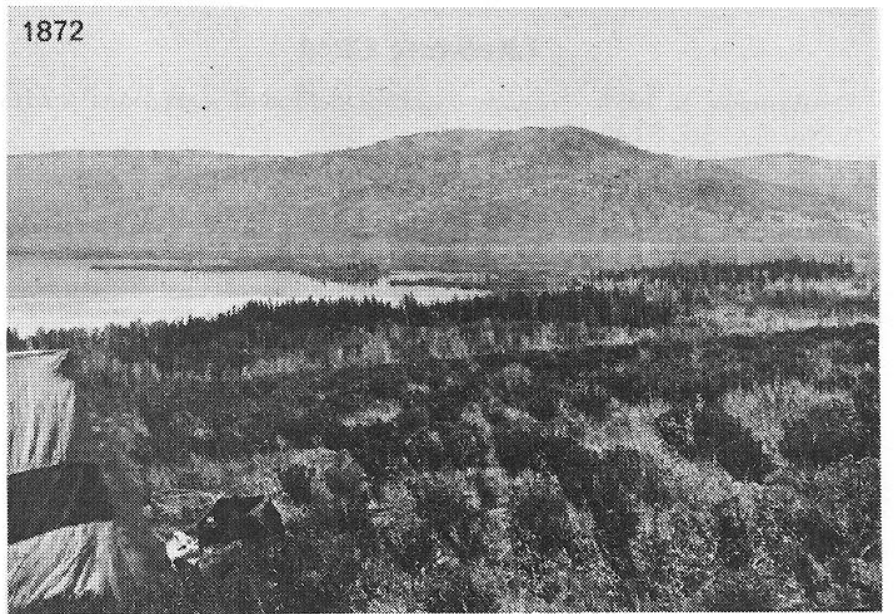

1981

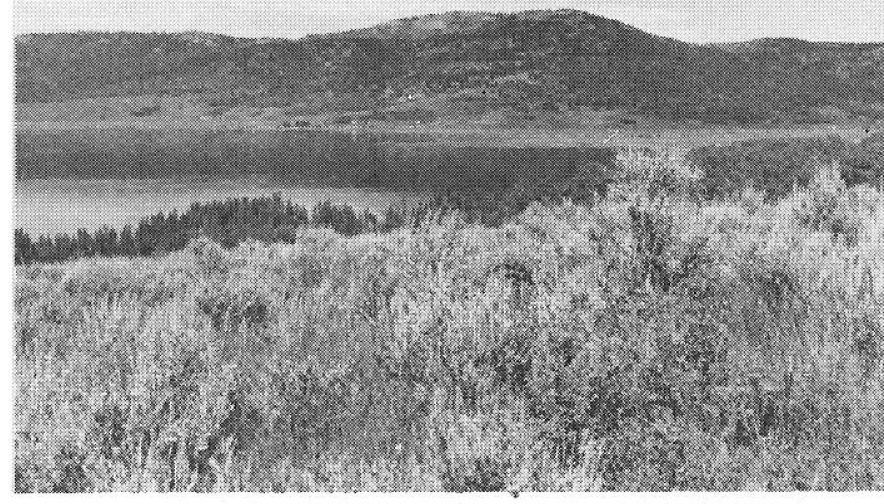

Fig. 1. Photographic comparison from the Henrys Lake study area (location in Figure 3).

1872: USGS photograph 178 by W.H. Jackson.

Looking west-southwest across the north end of Henrys Lake from the lower slopes near site now occupied by Wildrose Guest Ranch. Ground cover in foreground appears to be an association of herbs and scattered snowberry plants. The dark, clustered plant seems to be a woody-based forb, but could be rabbitbrush (Chrysothamnus viscidiflorus). Aspen in various successional stages are evident adjacent to lake. Far slopes show thinning effect of past fires on conifers.

June 25, 1981: Retake photograph by G.E. Gruell.

Foreground now supports a dense mountain big sagebrush stand. Associated vegetation includes scattered snowberry that is being outcompeted by sagebrush, Idaho fescue, bluebunch wheatgrass, and other perennial grasses and forbs. At right, aspen growth screens former view. Lake level was raised about 15 feet irrigation purposes. In distance, aspen stands have matured, while Douglas-fir density has increased markedly. 


\section{Procedures}

Evidence of fire history was gathered in the vicinities of 7 sites along the forest-grassland ecotone where early landscape photographs were available (Fig. 3). To obtain a more complete representation of fire history throughout the high valleys of southwestern Montana, we also sampled 5 additional sites that were geographically dispersed from those having early photographs. On each site we made a reconnaissance inspection to identify the habitat type (potential climax, according to Pfister et al. 1977) and current dominant vegetation. Apparent successional changes, such as conifer invasion or dead sagebrush beneath young conifers were recorded. We examined the fire-scar sequences on old-growth trees throughout each area, then chose 2 or 3 with the most intact and longest record of fires (Arno and Sneck 1977). Cross-sections were removed with a chain saw, taken to the laboratory, sanded, and annual growth-rings counted under magnification to identify the approximate date of each fire scar (Arno and Sneck 1977).
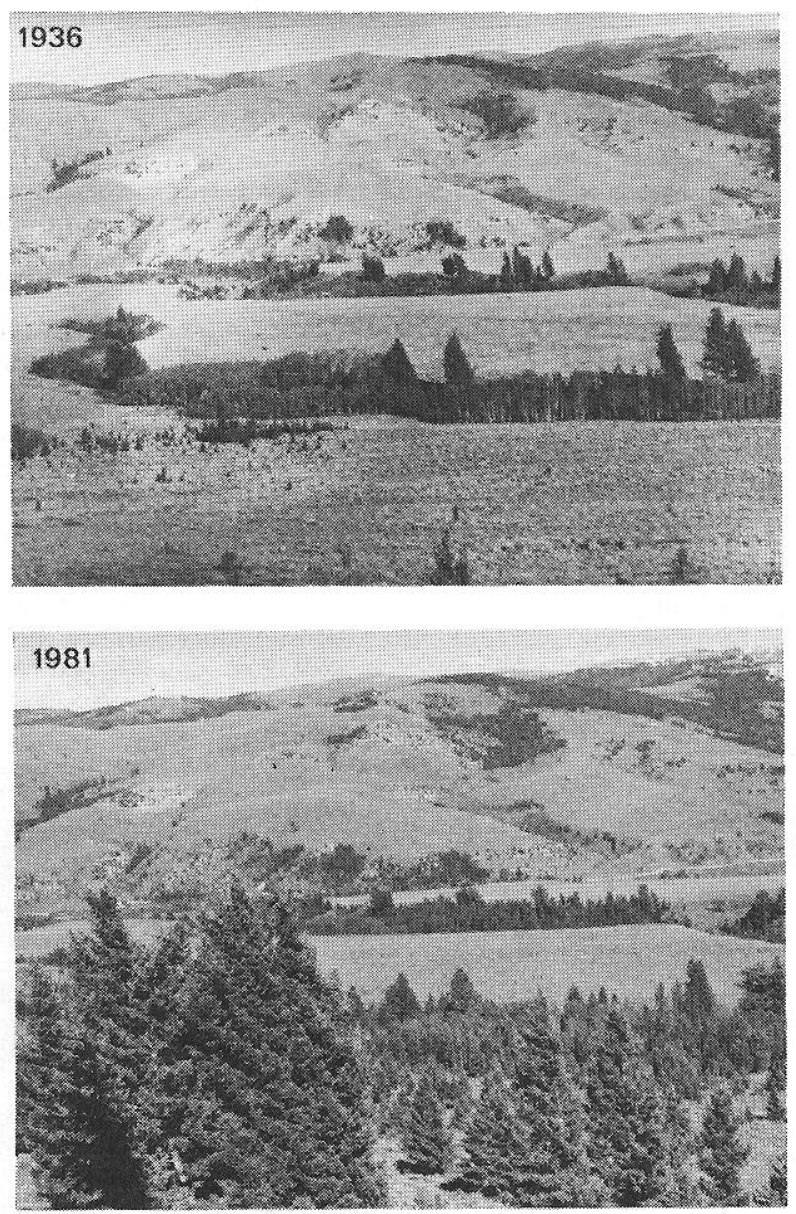

Fig. 2. Photographic comparison from the Vigilante area: August 1936: USFS photograph 330732 by Lincoln Ellison.

Looking east across Lewis (foreground) and Badger Creeks (midground) near Vigilante Station on the Beaverhead National Forest. The open slopes below (last burned in 1871) support a mountain big sagebrush community. Douglas-fir regeneration is occurring in the sagebrush at lower left. Thrifty aspen stands predominate along the drainages. Large Douglas-fir are also present. Douglas-fir, limber pine, Rocky Mountain juniper, and aspen comprise tree cover in distance.

June 2, 1981: Retake photograph by G.E. Gruell.

Young Douglas-fir now dominates the foreground, 45 years later. Dense growth of Douglas-fir along the drainages has resulted in intense competition and deterioration of aspen. In distance, conifers have regenerated slowly on dry sites, while on more moist sites the tree cover has increased substantially.

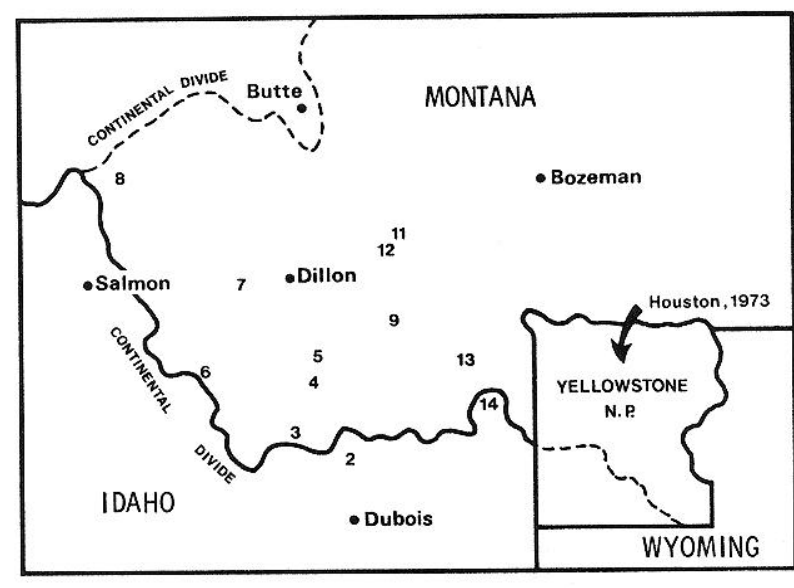

$\quad 20 \quad 40 \mathrm{ml}$

Fig. 3. Location of fire history sample areas. Area 2. Pleasant Valley; 3. Dutch Hollow; 4. Basin Creek; 5. Prices Creek; 6. Horse Prairie Creek; 7. Bannack; 8. Big Hole Battlefield; 9. Vigilante Station Area; 11. California Creek; 13. Papoose Creek; 14. Henrys Lake.

Six of the 12 sites (identified later in Table 1) were relatively moist and were Pseudotsuga menziesii/Calamagrostis rubescens habitat type, Calamagrostis rubescens phase (PSME/CARUCARU; Douglas-fir/pinegrass) or closely related types (Pfister et al. 1977). These fit into Fischer and Clayton's (1983) Fire Group Six-moist, Douglas-fir habitat types. Five sites were relatively dry. Pseudotsuga/Festuca idahoensis habitat type (PSME/ FEID; Douglas-fir/Idaho fescue) and fit Fischer and Clayton's Fire Group Five - cool, dry Douglas-fir habitat types. One especially dry forest-edge site was a Pinus flexilis/Agropyron spicatum habitat type (PIFL/AGSP; limber pine/bluebunch wheatgrass). This site fit Fischer and Clayton's Fire Group One - dry limber pine habitat types. All sites had ample evidence of several surface fires having swept through during the past few centuries.

Obtaining complete fire-scar records proved difficult on some of the sites because logging in the late 1800's removed much of the old-growth. Still, the old, deteriorated stumps remain, and the maximum number of fire scars on any of these stumps served as a benchmark reflecting the area's most complete fire history. We searched out the most complete scar sequences on living trees or sound snags, and were generally able to find scar sequences comparable to those on stumps. Often trees with fire wounds extending deep into the trunk proved to have more individual fire scars than were apparent externally. Some of these scars were "buried," in that they had healed over completely on the outer surface of the tree.

All sample trees had open catfaces with distinct wounds, folds of healing tissue, and charcoal resulting from multiple fires. The majority of sample trees were Douglas-firs, which generally form clear fire scars and can survive for several centuries with a large open fire wound (Figs. $4 \& 5$ ). This species has thick bark and is resistant to initial scarring by a surface fire; thus only trees that happened to become prominently scarred relatively early in life will be "fire-susceptible" and, with their open fire wound, serve as good recorders of subsequent fires. We avoided sampling the severely burned trees where repeated fires had possibly destroyed evidence of earlier fires.

In 8 of the sample areas, mean fire intervals (MFIs) were calculated based upon the fire dates from the single tree having the most complete fire record. In the 4 remaining areas, dates recorded on 2 nearby trees were combined to derive a "master fire chronology" (Romme 1980). MFIs were calculated using the time period between the first fire scar date and that of the most recent pre-1910 fire. (Organized fire suppression began in about 1910 in this region and only one of the study sites had recorded a post-1910 fire, a 1918 fire in sample area 2.) This time period was divided by the number 


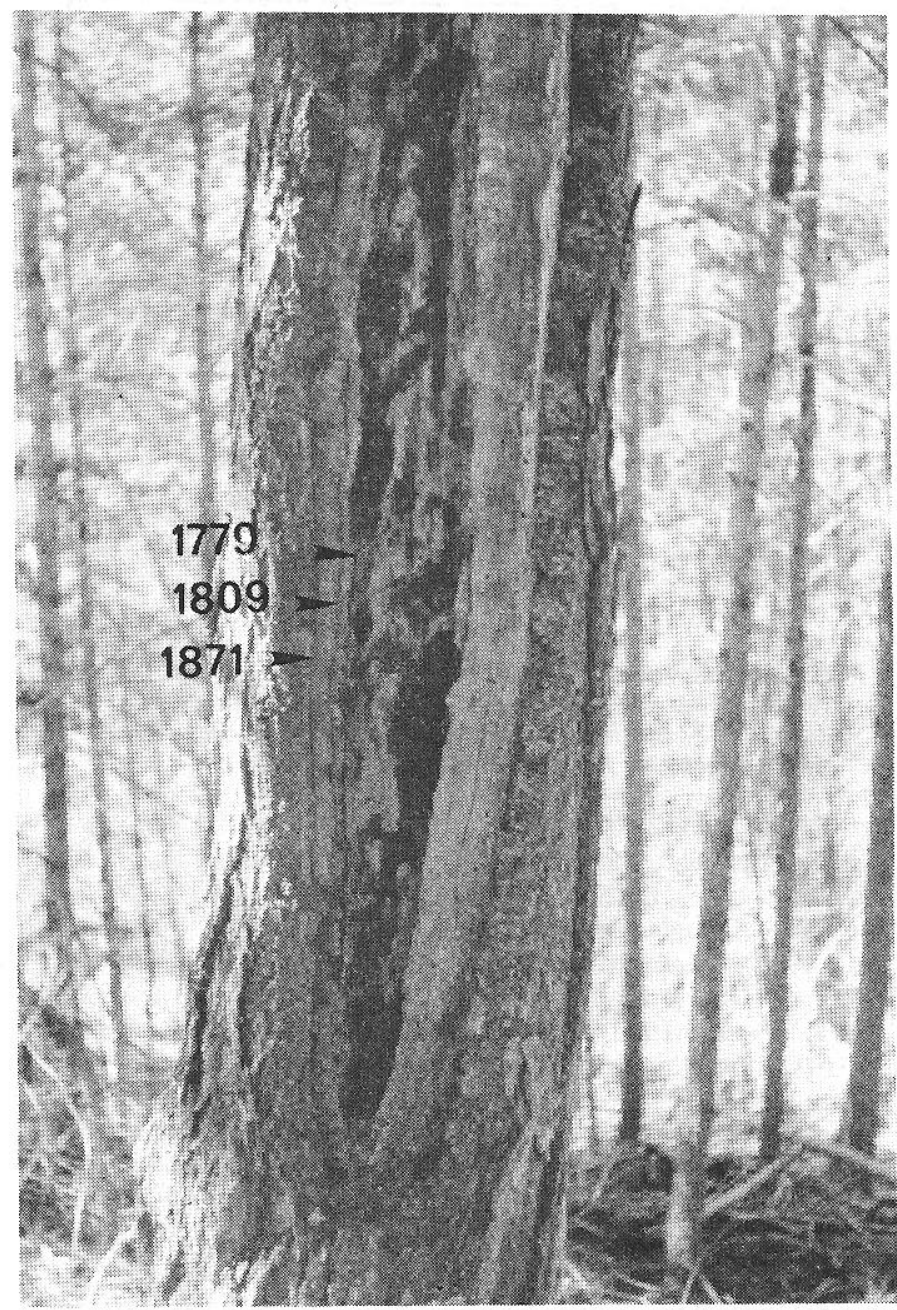

Fig. 4. Three fire scars $(1779,1809,1871)$ on a live Douglas-fir sampled on Badger Creek (area, 9 fig. 3). Nearby trees were scarred by still other fires during the same period. Dense Douglas-fir regeneration, resulting from absence of fire since 1871, appears in the background. of individual fire intervals occurring within it-number of fires occurring within it, minus one. In a few cases a fire scar seemed likely but not definite. These questionable fire scars were considered as $1 / 2$ of a fire for MFI calculations.

The resulting MFIs are a conservative estimate, possibly tending to overestimate the average time between fires at a given point on the ground. Such conservatism can be expected because of fires that were not detected, since they failed to scar even the previously scarred sample trees (Houston 1973, Arno 1976, Dieterich 1980). Also, one or more early fire scars might have been burned off by subsequent fires. This potential over-estimation of the length of MFIs seems more likely to occur in the dry, PSMI/FEID and especially the PIFL/AGSP habitat type, where fuels a re sparse and old-growth trees were often confined to rocky microsites. Short intervals might have gone undetected because of light fuel accumulation or slow tree growth, producing a poorly developed scar. Still, considerable effort and experience was employed to find the most intact fire scar sequences available on each site, and it seems unlikely that the resulting fire chronologies missed more than 1 or 2 spreading fires during the time periods analyzed.

\section{Results}

Table 1 summarizes the fire history findings for each site. Individual fire intervals ranged from about 5 to 97 years in the two major habitat types (PSME/CARU and PSME/FEID) or fire groups. MFIs ranged from 21 to 60 years and do not appear materially different by habitat type. The overall mean interval for pre- 1910 fires were 41 and 45 years on the 2 major habitat types. On the other hand, if we estimated that one fire was missed at each site per average recording period (214 years), which seems plausible, the resulting MFI for each of these two habitat types would be about 35 years.

Dates determined for fire scars a re shown in Figure 6. These data do not include sample areas 5 and 12, where actual dates of intermediate fires could not be accurately determined. Dates for the dry, PSME/FEID sites are only approximate because of extremely slow growth and the probability of missing rings, but this should have little effect on calculations of MFIs. Individual fire dates are spread throughout the recording periods, although on certain dates fires occurred in several of the areas. All 10 study areas burned between about 1789 and 1811 , for instance.

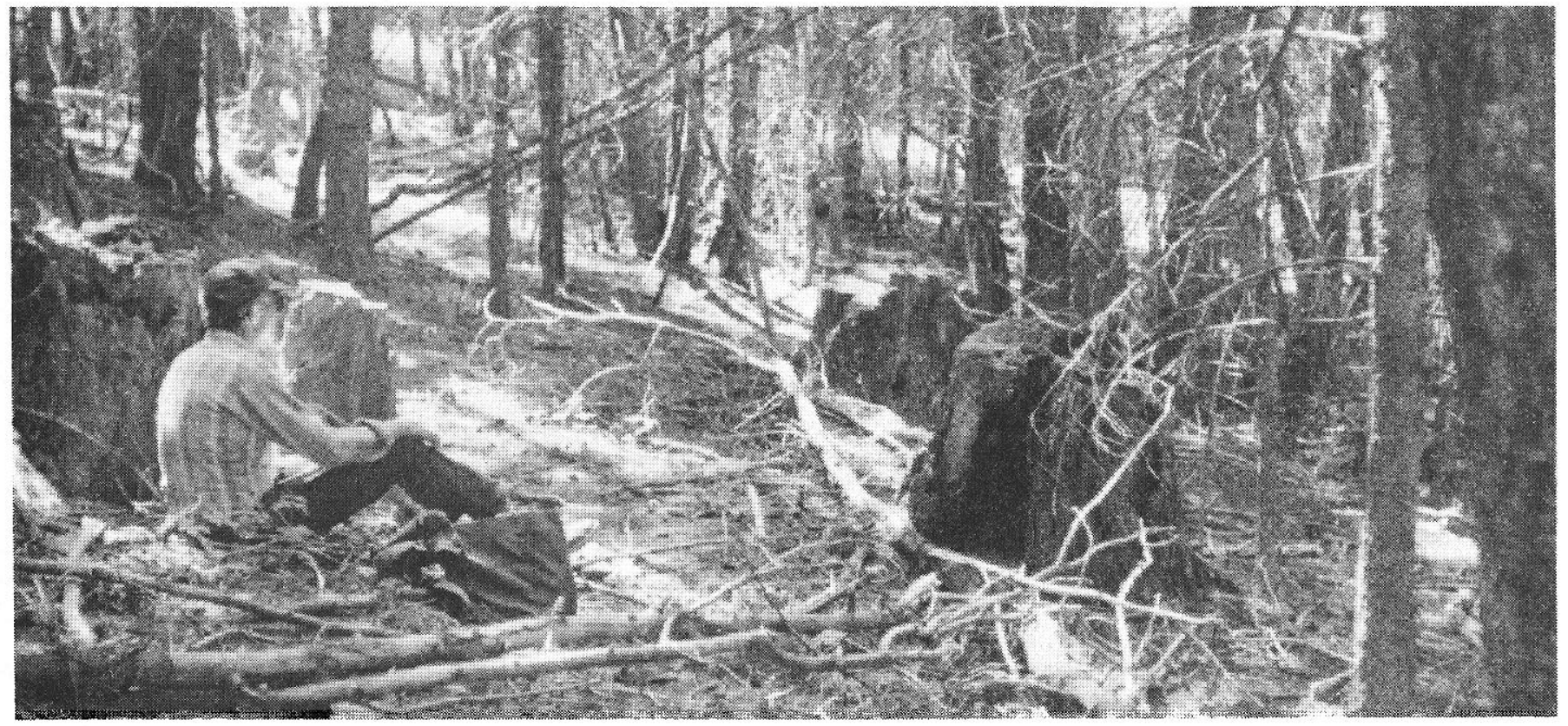

Fig. 5. Stumps of large Douglas-fir cut in early 1900's show that former stand was open and had been underburned repeatedly by surface fires. Stump at right was scarred by separate fires. Nearby live tree had fire scars from 1726, 1745, 1805, and 1890 (Dutch Hollow, area 3 in fig. 3 ). Dense pole sized Douglas-fir now dominates in the absence of fire (since 1890) and skeletons of quaking aspen appear in the foreground. 
Table 1. Fire history records for sample stands at the forest-grassland ecotone in southwestern Montana. Data come from fire scar sequences on one or a few trees having the most complete records on each site. (Dates shown are approximate.)

\begin{tabular}{|c|c|c|c|c|c|}
\hline $\begin{array}{l}\text { Sample } \\
\text { area no. }\end{array}$ & $\begin{array}{l}\text { Earliest and } \\
\text { latest fire dates }\end{array}$ & $\begin{array}{l}\text { Number of } \\
\text { fires detected }\end{array}$ & $\begin{array}{l}\text { Mean fire } \\
\text { interval }\end{array}$ & $\begin{array}{l}\text { Min. and max. } \\
\text { interval }\end{array}$ & $\begin{array}{l}\text { Number of fire-scarred } \\
\text { trees dated }^{2}\end{array}$ \\
\hline \multicolumn{6}{|c|}{ PSME/CARU ${ }^{3}$ (moist) habitat type } \\
\hline 2 & $1777-1854$ & 4 or $5(\div 41 / 2)$ & 22 years & $10-34$ years & 2 \\
\hline 3 & $1726-1890$ & 4 & 55 & $19-85$ & 1 \\
\hline $8^{4}$ & $1662-1902$ & 8 & 34 & $5-61$ & 2 \\
\hline 9 & $1734-1871$ & 6 & 27 & $7-32$ & 5 \\
\hline 11 & $1566-1856$ & 6 & 58 & $15-97$ & 1 \\
\hline \multirow[t]{2}{*}{13} & $1718-1865$ & 4 & 49 & $34-64$ & 2 \\
\hline & \multicolumn{5}{|c|}{ mean $=41$ years } \\
\hline \multicolumn{6}{|c|}{ PSME/FEIDs (dry) habitat type } \\
\hline 4 & $1609-1894$ & 10 & 32 & $6-53$ & 2 \\
\hline 6 & $1554-1795$ & 6 & 48 & $9-70$ & 2 \\
\hline 7 & $1585-1884$ & 6 & 60 & $10-94$ & 3 \\
\hline 12 & $1578-1886$ & 11 & 31 & $12-71$ & 2 \\
\hline 14 & $1694-1862$ & 4 & $\underline{56}$ & $31-69$ & 3 \\
\hline \multicolumn{6}{|c|}{ mean $=\overline{45 \text { years }}$} \\
\hline \multicolumn{6}{|c|}{ PIFL/AGSP 6 (hot, dry) habitat type } \\
\hline 5 & $1588-1877$ & 5 & 74 & $52-97$ & 1 \\
\hline
\end{tabular}

ILocations shown on Figure 3.

${ }^{2}$ As explained in text, MFIs were calculated based on the most complete records from one or two trees.

${ }_{3}^{3}$ Pseudotsuga menziesii/Calamagrostis rubescens and includes Pseudotsuga/Arnica cordifolia and Pseudotsuga/Symphoricarpos albus (Pfister and others 1977).

¿Data from this site include one fire date (1871) documented for our sample site by Pierce (1982).

'Pseudotsuga menziesii/Festuca idahoensis.

- Pinus flexilis/Agropyron spicatum.

\section{Interpretations of Vegetation Succession}

The photo comparisons from valleys of southwestern Montana show an increase in sagebrush and conifers over the past 100 years. Of 12 early photographs from nonforested sites, only one scene suggests heavy sagebrush at time of settlement. Nine photo comparisons indicate an increase in sagebrush density, while 2 scenes show no potential for sagebrush, none being in the vicinity.

Inspection of several sites confirms the photographic evidence of plant succession. Near the lower timberline, vigorous young conifer stands now occur on sites having few or no mature trees or stumps. Dead sagebrush (Artemisia tridentata, usually subsp. vaseyana), is often found beneath these new stands. Many of the scattered patches of aspen on these forest-edge sites have similarly been shaded out in the last 100 years (e.g., Figs. 1, 2, \& 5).

Both field inspection and photographic comparisons show that in the dry, PSME/FEID habitat types, trees were formerly confined to rock outcrops, talus slopes, and other microsites having surface rock and little vegetation or fuels. In the past century trees have spread from these apparent fire refugia to the less rocky areas that supported sagebrush and grass. In the more mesic (PSME/ CARU, etc.) habitat types, open stands of conifers (primarily Douglas-fir) bordered the grasslands, but, in the absence of surface fires, these stands have now filled in with an understory of young trees.

In moist habitat types, growth of Douglas-fir was evidently rapid enough to allow occasional trees to become established and reach sizes where they were less vulnerable to surface fires. On moist sites, it takes about $\mathbf{4 0}$ years for Douglas-fir to grow tall enough and to develop the corky outer bark that allows it to survive a light to moderate surface fire. On dry sites trees develop slowly and evidently few were able to reach a fire-resistant size by the time the next surface fire swept through the area. This contrasts with the warmer climates (at lower elevations) west of the Continental Divide and in central Montana where ponderosa pine grows. This species develops fire resistance (corky bark, open branching, large buds, and thick twigs) at a much earlier age than Douglas-fir; thus ponderosa pine was able to maintain itself in areas having surface fires at mean intervals of as little as 6 years (Arno 1980).

It is evident from our MFI estimates of about 35 to 40 years, and the even shorter 20- to 25-year intervals Houston (1973) estimated to east. Vertical bars designate the period used for calculating mean fire intervals (MFI). Dates with a question mark were calculated as $1 / 2$ fire. 
for similar habitat types in northern Yellowstone Park, that surface fires were rather frequent at the forest-grassland ecotone in southwestern Montana. In the somewhat drier grassland proper, MFI's probably were shorter. Considering that mountain big sagebrush in these high valleys is generally killed by moderate-to-hot wildfires and requires a few decades to spread back into large, hot burns (Blaisdell 1953, Harniss and Murray 1973, Wright et al. 1979), this species was probably much less abundant in the presettlement era. Conversely many native grasses and forbs could have prospered under the pattern of successive fire treatments portrayed by our data. This interpretation is consistent with Daubenmire (1959), who concluded that the original vegetation of the sagebrush-grass semidesert of western North America consisted of a dense cover of perennial grasses among which were scattered moderate-sized shrubs, chiefly Artemisia tridentata. Early narratives cite extensive, smooth grasslands in the Monida Pass (in 1857, Phillips 1925) and Henrys Lake-Raynolds Pass areas (Hayden 1872), whereas today dense stands of sagebrush are prominent there.

In the high valleys of southwestern Montana, sagebrush was probably the historical dominant on sites having either coarse (cobbly or sandy) or clayey soils (Morris et al. 1976). Grasses are poorly adapted to these soils, which have droughty surface conditions, whereas deep-rooting big sagebrush is well adapted.

In contrast, on the widely distributed loamy soils where most of the fire history work was done, 10 early photographs suggest that, prior to 1900 , sagebrush was restricted to small patches or widely spaced plants. These fine-textured soils have good potential to support dense stands of grass. This potential is suggested by investigations showing a predominance of perennial grasses on nearpristine range sites (Ross et al. 1973). Following fire on the finetextured soils, the perennial bunchgrasses apparently recovered in a few years and were present to fuel a subsequent fire. Conversely, extensive wildfires burning under hot-dry conditions would have resulted in nearly complete destruction of scattered sagebrush.

\section{Literature Cited}

Alexander, M.E. 1979. Bibliography and a resume of current studies on fire history. Canadian Forestry Service, Great Lakes Forest Res. Centre Rep. O-X-304.

Amo, S.F. 1976. The historical role of fire on the Bitterroot National Forest. USDA-Forest Serv., International Forest and Range Exp. Sta., Res. Pap. INT-187.

Arno, S.F. 1980. Forest fire history in the northern Rockies. J. Forest. 78:460-465.
Arno, S.F., and K.M. (Davis) Sneck. 1977. A method for determining fire history in coniferous forests of the mountain West. USDA-Forest Serv., Intermountain Forest and Range Exp. Sta. General Tech. Rep. INT-42.

Blaisdell, J.P. 1953. Ecological effects of planned burning of sagebrushgrass range on the upper Snake River Plains. USDA.

Daubenmire, R.F. 1959. Plants and environment. New York: John Wiley and Sons Inc.

Dieterich, J.H. 1980. Chimney Spring forest fire history. USDA-Forest Serv., Rocky Mountain Forest and Range Exp. Sta. Res. Pap. RM-220.

Fischer, W.C., and B. Clayton. 1983. Fire ecology of Montana forest habitat types east of the Continental Divide. USDA-Forest Serv., Intermountain Forest and Range Exp. Sta. General Tech. Rep. Int.-141.

Gruell, G.E. 1980. Fire's influence on wildlife habitat on the Bridger-Teton National Forest, Wyoming. USDA-Forest Serv., Intermountain Forest and Range Exp. Sta. Res. Pap. INT-235 and 252, Volumes I and II.

Harniss, R.O., and R.B. Murray. 1973. 30 years of vegetal change following burning of sagebrush-grass range. J. Range Manage. 26:322-325.

Hayden, F.V. 1872. United States geological and geographical survey of the territories-Idaho. Part I: 23, 56 and 57.

Houston, D.B. 1973. Wildfires in northern Yellowstone National Park. Ecology 54:1111-1117.

Morris, M.S., R.G. Kelsey, and D. Griggs 1976. The geographic and ecological distribution of big sagebrush and other woody Artemisias in Montana. Proc. Montana Acad. Sci. 36:56-79.

Patten, D.T. 1969. Succession from sagebrush to mixed conifer forest in the Northern Rocky Mountains. Amer. Midland Natur. 82:229-240.

Pfister, R.D., B.L. Kovalchik, S.F. Amo, and R.C. Presby. 1977. Forest habitat types of Montana. USDA Forest Serv., Intermountain Forest and Range Exp. Sta. General Tech. Rep. INT-34.

Phillips, P.C. (editor) 1925. Forty years on the frontier as seen in the journals and reminiscences of Granville Stuart. Arthur H. Clark Co., Cleveland, Ohio. Volume I.

Pierce, John R. 1982. A floristic study of the Big Hole National Battlefield. MS Thesis, Univ. Montana, Missoula.

Romme, W.H. (Committee chairman). 1980. Fire history terminology: report of the ad hoc committee. p. 135-137. In: Proc., Fire History Workshop; Tucson, Ariz. USDA-Forest Serv., Rocky Mountain Forest and Range Exp. Sta. General Tech. Rep. RM-81.

Ross, R.L., E.P. Murray, and J.G. Haigh. 1973. Soil and vegetation of near-pristine sites in Montana. USDA Soil Conserv. Serv. Bozeman, Mont.

Sindelar, Brian W. 1971. Douglas-fir invasion of western Montana grasslands. Ph.D. Diss., Univ. Montana; Missoula.

Stokes, M.A., and J.H. Dieterich (technical coordinators). 1980. Proceedings of the Fire History Workshop. USDA-Forest Serv., Rocky Mountain Forest and Range Exp. Sta. General Tech. Rep. RM-81.

Thwaites, R.G. 1959. Original journals of the Lewis and Clark Expedition. (Volumes 2 and 3). Antiquarian Press, New York. 5 volumes.

Wright, H.A., L.F. Neuenschwander, and C.M. Britton. 1979. The role and use of fire in sagebrush-grass and pinyon-juniper plant communities. A state-of-the-art review. USDA-Forest Serv., Intermountain Forest and Range Exp. Sta. General Tech. Rep. INT-58.

\section{BRANDAIDS Needed?}

Copies of BRANDAIDS, the booklet developed by the Society for Range Management to help ranchers weather the difficult financial climate, are available from the Society headquarters, 2760 West 5th Avenue, Denver, CO 80204. A single copy per individual for a single instance is available free of charge. Two to 100 copies may be purchased @75c each, postpaid; more than 100 are $50 \mathrm{c}$ each. Please allow 2 weeks delivery after receipt of your order. 